\title{
Cul-de-Sac Nightmares: Representations of Californian Suburbia in Science Fiction During the 1950s and '60s
}

\author{
James B. Mitchell
}

We can better understand twentieth-century American suburbs by situating and examining the fantasies they engender within specific practices of cultural production and consumption. Studying post-World War II suburbia as it appears in science fiction, a hugely popular multimedia genre that includes films, literature, and numerous other cultural expressions, can offer us productive insights into American culture as it is both imagined and lived. Science fiction (SF) texts not only provide us with glimpses into the ways in which these communities imaginatively construct identities and mythologies for themselves, but these narratives also, by virtue of their meticulous attention to detail, serve as rhetorical and cultural artifacts of lived experience. Indeed, in the latter half of the twentieth century American suburbia and science fiction have become inseparable - for the former is the lived experience of an imagined place brought to fruition in the dawn of the atomic age, while the latter is an aesthetic response to the uncanny conditions of living in a post-urban space. Postwar science fiction, with its satirical observations of society and inherently destabilizing, defamiliarizing narrative strategies, captures the alienating, disconnected sense of suburban synthetic communities in a way that no other cultural expression of this period approximates. ${ }^{1}$

Nowhere is this dynamic between SF and suburbia more compelling than in the Southern California municipalities that developed during and after World War II. This inquiry will briefly consider why the Southern California cultural climate of this era proved so hospitable to SF before examining some small towns and suburbs as James B. Mitchell is a Ph.D. candidate in the English Department at the University of Michigan. $\mathrm{He}$ is currently writing a dissertation on postwar science fiction and California. 
they appear in a few extremely influential SF texts of the 1950s and early 1960s: Ray Bradbury's Martian Chronicles, the television series The Twilight Zone, Don Siegel's film Invasion of the Body Snatchers, and Philip K. Dick's Time Out of Joint. Such a survey, admittedly far from exhaustive, suggests that much of the SF of this period offers elaborate critiques of American culture, especially the peculiar form of suburbia that became typified by Southern California communities in the boom years following the war. Two threads of these postwar SF critiques of suburbia merit closer consideration: a self-consciously futile impulse to create an idealized simulacrum of the nineteenth-century American small town in the environs of the suburbs, and an interrogation (often expressed through a fear of alien contamination) of the supposed integrity of the mid-twentieth-century nuclear family. These critiques articulate a resistance to both contemporary and retrospective constructions of 1950s America as "simple, innocent, happy, unanimously supportive of a broad spectrum of beliefs, or radically separated from the 1960 s by a culture of complacence, ... . [or as a] montage of sock hops, barbecues, suburban ranch houses, and a smiling Ike presiding over a contented electorate" (Foreman 1-2). ${ }^{2}$

During and following World War II, California loomed in the American cultural imagination as a sunlight-saturated factory of utopian dreams and superpower might. After all, California was not only the home of Hollywood and Disneyland, it was also the base for a burgeoning military defense industry that more or less reinforced the state's traditional bisection into two distinct regions: Southern California, with its aerospace plants and naval shipyards, manufactured war material, while Northern California, with its large research universities like Stanford and UC Berkeley, engaged in more abstract pursuits by developing technologies that permitted the acceleration of the nuclear arms race.

It is hardly surprising, then, that such a milieu produced a concentration of writers of speculative or science fiction, many of whom migrated to the golden state in the years between World War I and II. One of these writers, Edgar Rice Burroughs, founded a ranch that became Tarzana - the first suburb in the world to be named after a phenomenally successful SF character, Tarzan, Lord of the Apes. ${ }^{3}$ Other notable SF writers who moved to California at this time include Dianetics and Scientology creator L. Ron Hubbard (1918), Philip K. Dick (c. 1930), Ray Bradbury (1934), Robert Heinlein (1934), and Aldous Huxley (1938).

SF proved an amenable genre for California writers for a host of reasons. PostWWII California, with its seemingly irreconcilable contradictions - it was simultaneously one of the nation's most developed and most agricultural regions-proffered to Americans a real and fantastic space upon which they could map their desires. John Findlay notes that the state became overwhelmingly (sub)urbanized in this period: "In 1962 California passed New York to become the most populous state, and shortly thereafter it surpassed New Jersey as the most urbanized state. Almost 60 percent of the inhabitants of the eleven western states lived in California, and 25 percent of them resided in or around Los Angeles" (20). Yet California was also enormously agricultural, yielding more crops than any other state during the same years. It was the manufacturing of Cold War weaponry that provided California, especially the southern counties of Los Angeles and Orange, with unprec- 
edented federal capital for urban expansion and development, resulting in geometric growth that by the 1970s had threatened to destroy what was left of the natural environment. As one historian of this era remarks, "the prototypical community created by this Cold War activity was Orange County, the dream environment of the 1950s, a land of affluent white people, barbecues, Bermuda shorts, oranges, and surfing" (Markusen 51). As Southern California communities seemingly sprawled infinitely outward, SF offered nightmarish visions of suburban existence that belied the sunny mythology of easy golden state living - the "California lifestyle"-that had by the mid-1950s already become a commodity of sorts.

It is hardly coincidence that a disproportionate number of the postwar SF writers who ended up living in Southern California suburbs, including Bradbury, Dick, and Heinlein, originally hailed from small Midwestern towns (the first two from Illinois, the last from Missouri). Waves of intra-continental migration throughout the twentieth century ensured that "Los Angeles developed much as a Midwestern town transplanted onto the Southern California landscape" (Brodsly 74). Frequently appearing as a nostalgic, utopian recreation of a late nineteenth-century Midwestern burg, the small town-virtually trademarked by Bradbury in his SF tales and reified by Walt Disney in his Main Street, U.S.A.- - is an idyllic, fantastic place to which one can never return (and which, of course, never actually existed in the first place). Imagined during the same period in which many California SF writers were plumbing the contradictions of suburbia, and built in a region of industrialization dubbed the "gunbelt" by some Cold War scholars, ${ }^{4}$ Disney's reconstruction of an uncannily ebullient small town in the shadow of Los Angeles illustrates the postwar urge to reclaim an American civic life that had long been idealized but rarely realized.

Disneyland, a baroque, nostalgically rendered park situated in a suburb of L.A., offers, as it were, a small town once removed in its simulacrum of Main Street, U.S.A. Disney and his Imagineers ${ }^{5}$ modeled Disneyland's Main Street on the impresario's boyhood small town of Marceline, Missouri. Because Main Street serves as a gateway to all the other regions of the park, one must pass through and experience small-town America as envisioned by Disney and Company. What is perhaps most astonishing about Disneyland's romanticized portrayal of America (the robotic Abe Lincoln, the "Rivers of America" cruise) is the glaring absence of California itself - the park makes no attempt whatsoever to represent or historicize "California." The absence of California history amidst a surfeit of Americana reinforces the state's long practice of willful amnesia, a custom only exacerbated by processes of suburbanization that attempt to elide all traces of the past. Joan Didion observed in the late 1960s that "the future always looks good in the golden land, because no one remembers the past" (4). Disneyland imagines California as a scrubbed palimpsest, a blinding white movie screen upon which anything - save stories of California's actual past - can be projected.

Main Street, U.S.A. is undoubtedly a palliative for the disconnectedness of living in a sprawling horizontal suburb. ${ }^{7}$ It provides a fabricated sense of community in the form of a sanitized town center: its boulevards are steam cleaned daily, its paths mitigate freeway-induced feelings of anonymous claustrophobia by offer- 
ing the illusion of freedom while controlling all movements of its populace-all guests are free to travel wherever they please, provided they walk on meticulously engineered sidewalks or ride in vehicles whose routes are predetermined. Disneyland, the self-proclaimed "happiest place on Earth," allows its guests to visit (and not, significantly, to live in) a small town; such a sojourn, however, comes at a high ideological and economic price. ${ }^{8}$

One tremendously popular California SF writer concerned with the problem of restoring the nostalgia of small-town Midwestern America to the new, technologically obsessed suburban enclaves is Ray Bradbury, a man who, like Walt Disney, was born in the Midwest. Living his adult life in Los Angeles, the metropolis with the most extensive freeway system in America, Bradbury ironically never learned to drive an automobile. He did, however, write numerous essays lamenting the lack of a town center in the notoriously fragmented metropolis:

Olvera Street ... fulfills many of my requirements, as does, on a large scale, Disneyland. You can indeed sit, eat, lounge, stare, at Uncle Walt's, but you don't really go there to shop, and it isn't a community center, but a Southern California asset. Century City qualifies in many ways. But it has no true center .... The Santa Monica mall suffers for similar reasons. It has no true center. ("The Girls Walk this Way" 12)

Bradbury's Martian Chronicles, a collection of stories depicting various human attempts to colonize Mars, shares a number of striking parallels with the historical settlement of the American West (e.g., the native Martians are eradicated by a communicable disease and their culture is effectively misunderstood and destroyed by the invading humans who, in this case, are primarily white American males). Both Disney and Bradbury invoke nostalgia to portray their versions of American history: the former in a facile, reassuring manner that encourages complacency while eliding difference, the latter in a more provocative, open-ended fashion that questions progress without completely undermining American pioneerism. Not surprisingly, Bradbury has been an avid fan of Disneyland his entire life, writing several encomia for the place and its builder. 9

Unlike Disneyland, whose Tomorrowland explicitly champions the myth of progress while downplaying the possible negative ramifications of technology, Bradbury's book presents a problematic vision of the future: its stories celebrate small-town America and the romance of westward expansion while simultaneously revealing the futility of reconstructing the small town in an age of atomic energy. One story from The Martian Chronicles, "The Third Expedition," aptly depicts the futility of such an endeavor.

The title of the story refers to the Earth men's third journey to the planet Mars. ${ }^{10}$ Upon the rocket's landing, each crewmember believes that he sees a recreation of his own hometown in the Martian countryside: one sees Green Bluff, Illinois, another Grinnell, Iowa. Expecting an alien environment, the men instead view "a tall brown Victorian house, quiet in the sunlight, all covered with scrolls and rococo, its windows made of blue and pink and yellow and green colored glass ... Through the front window you could see a piece of music titled 'Beautiful Ohio' 
sitting on the music rest" (33). The Martians have deceived and caught the men off guard by presenting them with what they most desire-a chance to return to the simple pleasures of small-town America. The Martian town is actually an exact replica of the captain's boyhood town (which was built in 1886), a kind of place that by the story's “April 2000" date had become extinct. Even the expedition's archaeologist is fooled by the replica, thinking aloud, "It's a small town the like [sic] of Earth towns .... Incredible. It can't be, but it is" (33). Not only are the details of the town convincingly counterfeited, but long-dead relatives also appear to greet the men and lull them into complacency.

The Martians' successful invocation of the pastoral mythology of the small town has a deadly narcotic effect on the captain and his men: "It had been thirty years since he had been in a small town, and the buzzing of spring bees on the air lulled and quieted him, and the fresh look of things was a balm to the soul" (37). The men separate from their military fellowship, each retiring to sleep with his respective family (the extended family of the frontier town is made whole again, if only temporarily). The fantasy of the small town proves short-lived, however. As he falls asleep, the captain reflects on the possibility that his mind has been read; before he can act, however, the Martians murder the entire crew. Thus the colonizers can dream of the small town, but they cannot, despite their most fervent wishes, ever reinvent it.

Intriguingly, the Martians continue the charade even after all the humans are killed, holding a somber small-town funeral: "The brass band, playing 'Columbia, the Gem of the Ocean,' marched and slammed back into town, and everyone took the day off' (48). This final scene is certainly comically macabre, yet it can also be read as a satirical criticism of American imperialism. For instead of planting a flag and claiming territory, the explorers, leaving behind fragments of their popular nationalistic culture, have themselves become incorporated into the Martian landscape with a wicked pun - "Earth pounded down on the coffin lids" (48). Bradbury's tale suggests that the fantasy of small-town America, wistfully imagined by technologically-dependent suburbanites, remains perpetually elusive in the postwar age.

The memorable series The Twilight Zone delighted in exploring how SF small towns, although picturesque, were always chimerical, unreal vestiges of an idealized way of life. The series was created by Rod Serling, an upstate New Yorker transplanted to the chic L.A. suburb of Pacific Palisades in the years following the war." In a notable episode entitled "Stopover in a Quiet Town," a New York City couple who spend the night at a cocktail party in the country awaken to find themselves in a strangely deserted small town called "Centralville." The town's name is multivalent, for it refers both to the mythological prominence of the middleAmerican "heartland" in the nation's cultural imagination and to the inescapability, the gravitational pull as it were, of this myth: at one point the couple attempt to leave Centralville via train, only to arrive back where they started.

Periodically hearing a child's inexplicable giggle, the couple soon discover that the "town" is a complete mock-up, a life-sized replica similar to a Hollywood backlot. Everything in the town is a convincing prop, down to the ersatz squirrels climbing on synthetic trees. We can recognize here not only the classic SF trope of the false 
city, ${ }^{12}$ but also a self-reflexive ironic commentary on the illusory nature of the film and television industry. The male disparagingly refers to the town as "Hicksville," griping about the eeriness of the otherwise quaint deserted town: "I don't see how they stand it in this small-burg ... . Give me the big city any day. At least there you know when you're being stared at." Curiously enough, the episode unfolds in a hyperrealistic narrative fashion until the SF denouement attempts to explain the mystery of Centralville: in the episode's last shot we hear the girl's giggle again, see a giant hand scoop up the now Lilliputian couple, and hear an admonishing adult voice say: "Be careful with your pets, dear, daddy brought them all the way from Earth." The couple are doomed to spend their days as an alien child's playthings in a "human zoo" on another planet. Their awful fate reminds us that the California culture industry can emulate or import the Midwestern small town, but it cannot breathe life into it. Ultimately, the postwar SF small town, whether it is imagined in a themepark, on Mars, or in a Hollywood studio, can be visited but never inhabited. It appears, incessantly, as a tantalizing simulacrum to the denizens of suburbia.

Of all SF municipalities, the suburb is the most uncanny. Promoted as a hygienic antidote to the metropolis, the SF suburb promises to inoculate its residents against the contaminating influence of the big city while recreating the communal fantasy of the small town. Kenneth Jackson's claim that "at the heart of all suburban growth is land development - the conversion of rural or vacant land to some sort of residential use" (133) seems especially relevant to discussions of Southern California suburbia. Southern California suburbanization is, above all, a process of mandatory forgetting, as if the creation of a modern utopia were made possible solely through the denial of a historical past. In the dominant postwar logic of Southern California suburbia, a development truly succeeds only when the area it comprises has undergone a "geographical cleansing," such that what remains is completely unrecognizable from what was there before. ${ }^{13}$

In the latter half of the twentieth century, Southern California epitomizes ersatz suburban living: its suburbs are culturally separated not only from the pastoral or rural (which Twain, Cather, Hemingway and others throughout American literature locate predominantly in the Midwest and sometimes the South) but are also, because they lack recognizable hubs, quite distinct from the great city centers of the East and Europe (San Francisco is perhaps the closest analogue to an Eastern city in the entire state). ${ }^{14}$ This condition of "suburbanity" permeates all discussions of culture in southern California, a place where living is predicated upon technologies, the automobile in particular. Richard G. Lillard commented upon this peculiarity in 1968 , noting that "the pedestrian, around whom all civilization centered until the automotive era, disappeared in California after cities began to roll outward on rubber tires. Footwalkers are so rare now as to be suspicious characters in exclusive residential areas" (97).

What separates the suburb from the small town is its reliance on technologies - the indispensable expressway, the requisite automobile, the labor-saving domestic appliance - with which it purports to liberate its residents from the overcrowding of the metropolis as well as from the necessity of cohabiting with extended family members. In doing so the suburb often becomes a zone of exclusion, 
a select community into which anyone can be inducted, provided he or she has the right cultural and economic capital (not to mention religion and ethnicity). ${ }^{15}$

We can supplement Robert Fishman's assertion that suburbia is "the collective creation of the Anglo-American middle class: the bourgeois utopia" (x) by pointing out that the fantasy of the nuclear family attends this creation, bringing with it the anxiety of conformity and the fear of being scrutinized under the watchful eyes of neighbors, people who, though they appear very similar to one another (otherwise how could they live in the same neighborhood?) are somehow nevertheless just a little different. Unlike other postwar expressions of popular culture (television sitcoms, for example), ${ }^{16}$ much of the SF of this era depicts suburban nuclear families as fragile; those few that are intact survive only by virtue of tenuous relationships. Invasion poses a grave threat to the suburban fantasy of familial integrity, a menace to which the suburban enclave responds by enshrouding its xenophobia in the rhetoric of community bylaws. When the usual markers of difference (race, class, ethnicity, sexual orientation) are illegible to the gatekeepers of suburbia, anxiety and, eventually, violence grip the community. ${ }^{17}$

Perhaps the SF suburb film that best captures the xenophobia of the postwar age is Invasion of the Body Snatchers, which takes place in the fictitious locale of "Santa Mira, California" (it was actually filmed in Sierra Madre, an L.A. suburb in the foothills of the San Gabriel Mountains). The campy movie has infiltrated American popular culture so thoroughly and is so frequently associated with the "red scare" of the 1950s that its plot is familiar even to many who have never seen it: alien doppelgängers growing from vegetative "pods" gradually infiltrate the sleepy suburb of Santa Mira and replace its citizens. Besides lacking emotional affect, the aliens exhibit "no difference you can actually see." This foreign contamination creates consternation within the suburb for obvious reasons-the heroes (the white, middle-class Californians Dr. Miles Bennell and Becky) cannot proactively discriminate against the aliens as they might against undesirable ethnic or religious minorities because the body snatchers are a virtually imperceptible enemy who look just like everyone else.

The film is frequently read as a crude political allegory warning against the insidious omnipresence of communist fifth columnists: in a caricature of life within the system of Soviet communism, one of the snatchers, urging Miles to capitulate, assures him that "without love, ambition, desire, faith, life is so simple." The film's implied horror, then, lies in surrendering the right to experience these four emotions, all of which are presumably guaranteed under capitalism.

Yet the film can also be conversely read as a diatribe against the constricting conformity of suburban existence and the inadequacy of the nuclear family to avert catastrophe. We get our first glimpse of the epidemic in a scene in which a young boy runs away from his mother claiming that she is not "herself." Although nuclear family members are the first to witness the effects of the body snatchers, they are incapable of responding to the threat. The two main characters who do manage to resist the invasion deviate from the 1950s suburban norm - they are both divorced, single, childless professionals. A key difference between Becky and Miles is that she lives with her elderly father (depicting a single, divorced, childless woman who 
also lived outside the auspices of a patriarch would be too subversive even for SF of the time), whereas Miles is entirely without family. Becky's resistance is only partly successful, however: she succumbs to sleep near the film's end (rendering her vulnerable to assimilation) and becomes an alien herself. Miles alone survives the invasion by fleeing on the highway, the nexus connecting Santa Mira to all the other California suburbs (and also the means by which the pods are imported from outlying rural areas). ${ }^{18}$ Thus SF exposes the suburban nuclear family as fragile and unstable: a liability masquerading as shelter, it ostensibly promises security but instead delivers nightmares.

Philip K. Dick, a Northern Californian who settled in Orange County in the early 1970s, explores similar nightmarish suburban themes in his novel Time Out of Joint. Dick's work is highly regarded by postmodern theorists, such as Fredric Jameson, who see it as an exposition of the paranoia inevitably generated by consumer culture:

Indeed, of the great writers of this period [1950s], only Dick himself comes to mind as the virtual poet laureate of this material: of squabbling couples and marital dramas, of petit bourgeois shopkeepers, neighborhoods, and afternoons in front of television, and all the rest. But, of course, he does something to it, and it was already California anyway. (519)

Dick's novels expose the seamy underside of the California suburban utopian dream without making any attempt to reconcile its contradictions. Dick frequently commented on the synthetic qualities of California suburbia in personal correspondence and essays, describing Fullerton (near Disneyland in Orange County) as "a plastic, clean, dope-free, expensive, modern, dull city with no scenery .... I rented an apartment and drilled down into the concrete to establish prefabricated roots . . . . I sort of identify with this wretched place, where a scenic wonder is a dried-up swamp and the national bird is a buzzard" (Letter 31). It is no wonder that Dick's characters ultimately remain hopelessly psychically splintered as they strive to overcome the debilitating schizophrenia that unerringly accompanies living in these pseudo-cities.

In Time Out of Joint a conspiratorial government dupes the protagonist Ragle Gumm into believing he lives in a 1950s utopian suburb (the city, dubbed "Old Town" by those in the know, is actually a simulacrum constructed in 1997 in a postapocalyptic world)..$^{19}$ The elaborate gambit is designed to extract a certain intellectual labor from Gumm: by means of a complex method of discerning patterns-he thinks he's solving a daily newspaper puzzle-Gumm accurately predicts where nuclear bombs being hurled by lunar revolutionaries challenging the fascist hegemony of the terrestrial government will land.

The first one-third of Time Out of Joint portrays a carefree utopian California lifestyle that had even by the late ' 50 s become stereotypical. Neighborhoods abound with "kids romping, cows mooing, dogs wagging. Men clipping lawns on Sunday afternoon, while listening to the ball game on TV" (108). Save for a few key government agents and members of the resistance movement, all of the suburbanites, because they have patriotically volunteered to have their memories erased, are 
utterly unaware that the town is a sham. Gumm himself requires no brainwashing because he has aided the government's construction of the town by regressing into an "infantile psychosis" - the town is an idealized reconstruction of his own boyhood suburb. Thus Dick in this novel has combined the nostalgia for the SF small town with the fantasy of the postwar suburban paradise. Neither the small town nor the suburb will survive his treatment, though, for the book reflexively acknowledges that the 1950 s it painstakingly depicts (which resembles in many respects the fantasies of family sitcoms) never really did exist, a rather astonishing feat given that Dick composed it without the benefit of hindsight squarely in the middle of that decade.

A crucial insight of Dick's work is that "suburbanity" is at its heart a performance, the script of which can be gleaned from media culture. Indeed, the citizens of Old Town possess no identity outside their role within the suburb, a part dictated to them by the government and media. In a scene that dramatizes this convincingly, Ragle takes time off from his newspaper contest to visit the city's park with Junie Black, a neighbor. The park epitomizes the postwar California suburban utopiathe sun shines brightly on the children frolicking in the swimming pool, an ice cream vendor rings his bell. Ragle, however, soon finds himself complaining to Junie about the suburban aspirations of his ex-wife, who "wanted nothing but to get up in the class where she'd be giving garden parties. Barbecues in the patio." Junie musters a half-hearted response by citing a popular lifestyle magazine: "It's natural to want to live graciously.' She had got that term out of Better Homes and Gardens, one of the magazines she and Bill subscribed to" (46). Shortly thereafter, Ragle has a moment of "clarity" that leads him to question the reality of his world when he briefly sees through the fabric of the concocted illusion of suburbia. The narrative is not merely poking fun at Junie's bourgeois tastes; it is indicting the entire fiction of suburbia, a place where ontology solidifies with the recitation of brand names.

One of the novel's most scathing indictments of suburbia concerns the dissolution of Old Town's nuclear families. Once Ragle (another single, divorced protagonist) has successfully escaped, Bill Black, the military officer in charge of running the suburb, drops the façade and informs Margo, Ragle's supposed "sister," that the familial relationships are all contrived: Ragle is no relation to her, and her husband Vic is actually a stranger: "It so happens that you and I are married. But your personality-type fitted in better as a member of Ragle's household. It had to be arranged on a practical basis" (241). The nuclear family, fragile at best in postwar SF, disintegrates before the onslaught of efficient government conspiracy. Rather than a source of solace, the nuclear family is a divisive originator of distress.

Margo's final vision of suburbia neatly encapsulates cul-de-sac nightmares:

Sixteen hundred people, standing in the center of a stage. Surrounded by props, by furniture to sit in, kitchens to cook in, cars to drive, food to fix. And then, behind the props, the flat, painted scenery. Painted houses set farther back. Painted people. Painted streets. Sounds from speakers set in the wall. Sammy [her false son] sitting alone in the classroom, the only pupil. And even the teacher not real. Only a series of tapes being played for him. (238) 
Ultimately, SF, which has proven itself to be the dominant popular generic expression of the last fifty years, offers us alternative ways of reading postwar American civic culture because it questions the ideology of suburbia and all of its trappings - the compulsion to consume domestic technologies, the lust for paving over natural areas, the fetishization of the nuclear family. SF's popular success, though, often works against serious acceptance of the genre's cultural critiques. If we hope to understand the myriad complexities of the postwar American suburb, we must consider the legacy of SF alongside other contemporary expressions of popular culture.

\section{Notes}

${ }^{1}$ To be sure, SF was hardly the only cultural expression that challenged the middleAmerican hegemony of the 1950s. Rarely, however, do scholars studying dissent and nonconformity in 1950s American literature look to this popular genre. Most focus instead on the works of such writers as James Baldwin, Ralph Ellison, Norman Mailer, J. D. Salinger, Richard Wright, and those commonly associated with the Beats (William S. Burroughs, Allen Ginsberg, Jack Kerouac, et al.).

${ }^{2}$ A full-length study of 1950 s SF in comparison with the Beat movement seems overdue, particularly when one considers William S. Burroughs's widespread use of SF tropes in his fiction as well as his subsequent influence on writers of cyberpunk (not to mention that his heroin manifesto Junky was first published by Ace Books, an SF imprint, in 1953).

${ }^{3}$ The city was named Tarzana in 1927.

${ }^{4}$ Ann Markusen notes that within the "gunbelt," defense-industry oriented geographical regions

accounting for a major increment in population and jobs in the postwar period . . are localities that captured the American imagination as either sunny, suburban paradises (Los Angeles, Orange County, San Diego) or yuppie high-tech enclaves of the future (Silicon Valley, Route 128 outside Boston, Seattle). Greater Los Angeles, home also to Hollywood and Disneyland, became the military-industrial capital and center of gravity of the gunbelt.

5 "Imagineer" is the corporation's term for the creative consultants who design the themepark's attractions.

${ }^{6}$ This oversight is only highlighted by "California Adventure," the new themepark constructed adjacent to Disneyland in 1998-2000, which attempts to portray a microcosm of the state by showcasing stereotypical "Californiana," such as vineyards, boardwalks, etc.

7 The twenty-first-century iteration of this is the new "Downtown Disney," a pedestrian shopping mall built over the themepark's former sprawling parking lot. As Michael Sorkin notes:

Disneyland was not simply designed for arrival by car, but was-like Los Angelesbegot by the car. One approaches Disneyland only after tooling across the vast Southern California sward of atomization, the bygone suburban utopia of universal accessibility that the automobile was supposed to guarantee. Whatever else it represents, Disneyland is also a model of Los Angeles. Fantasyland, Frontierland, Tomorrowland-these are the historic themes of the city's own self-description, its main cultural tropes. (217) 
${ }^{8}$ For an account of living in Celebration, U.S.A., the Disney Corporation's effort to reinvent small-town living at the end of the millennium, see Ross.

${ }^{9}$ Richard Schickel relates a telling anecdote:

Bradbury ... once conceived the notion of having Disney run for mayor of Los Angeles on the not completely unreasonable ground that he was the only man with enough technological imagination to rationalize the sprawling mess the megapolis had become. He journeyed out to the studio to put the idea to Disney, who was flattered but declined the opportunity. "Ray," he asked, "why should I run for mayor when I'm already king?" (364)

${ }^{10}$ Unbeknownst to the third expedition, the first two forays ended in disaster: the indigenous Martians, who are skilled telepaths, managed to thwart the previous expeditions by reading and influencing the humans' minds.

"Serling, who spent his youth reading pulp SF magazines like Amazing Stories and Astounding Science Fiction, even managed to enlist Ray Bradbury to write an episode for his series (Bradbury adapted his short story "I Sing the Body Electric!" for a 1962 episode of the same title).

${ }^{12}$ A few recent popular cinematic examples include The Thirteenth Floor, Dark City, The Matrix, and The Truman Show.

${ }^{13}$ Works like the Stephen Spielberg produced SF/horror film Poltergeist melodramatically but nevertheless poignantly depict the repercussions of paving over history. The Freelings, a nuclear family living in the California suburban development of "Cuesta Verde Estates," discover through a series of events that paranormal spirits are plaguing their family because their tract home has been built over a sacred Native American burial ground.

${ }^{14}$ David Brodsly writes:

Suburbs in the East, defined in relation to an older sector of a city, offered an escape from a dense urban core. Residential patterns in Los Angeles, on the other hand, were commonly all suburban. It was a city of single- and two-family detached homes, a category that, as late as 1930 , comprised 93 percent of all dwellings. In comparison, Chicago had 52 percent and Boston 49.5 percent detached housing. Whereas 32 percent and 27 percent, respectively, of families in those cities owned their own homes, in 1930 the Los Angeles figure was 40 percent. (76-77)

${ }^{15}$ In 1958 Robert Wood listed some of the common exclusionary tactics employed by suburbs, such as "the judicious use of regulatory powers, special requirements and restrictions demanded of builders, discrimination in taxation and in the quality of services extended to particular neighborhoods, selective annexations, [and] imaginative employment of eminent domain" (218).

${ }^{16}$ Sociologist Stephanie Coontz is being only slightly facetious when she identifies the ideological instructions of the 1950s sitcoms as follows: "You too can escape from the conflicts of race, class, and political witch-hunts into harmonious families where father knows best, mothers are never bored or irritated, and teenagers rush to the dinner table each night, eager to get their latest dose of parental wisdom" (39). The Twilight Zone episode "The Monsters are Due on Maple Street" exemplifies this difference well. The episode opens with a voiceover that melds the utopianism of the small town with the amenities of the suburb: "Maple Street, U.S.A. Late summer. A tree-lined little world of front porch gliders, barbecues, the laughter of children, and the bell of an ice cream vendor." A flash in the sky (UFO), followed by a power outage, dissolves the serenity of this suburb. Friends turn against friends, family against family, as the residents accuse one another of abetting the (unseen) aliens. Conflict escalates into a full-blown riot that demolishes the entire street 
while bemused aliens remotely watch the humans self-destruct.

${ }^{17}$ Richard Weinstein writes:

The village was the settlement pattern that most appealed to those who considered moving to Southem California: it was promoted as the return to village ideals and the simple life, an antidote to the blight of demoralizing metropolitanism. These provincial ideals also placed a value on social harmony and the absence of conflict, and hence this exclusion of nonconforming racial groups, to allay the anxieties associated with the move west. The promoters of Southern California real estate promised at the same time the recovery of an idealized life of the village in a rural setting and the opportunity for personal fulfillment. (28)

${ }^{18}$ The migrant laborers who actually work in the rural fields of California are invisible in this film.

${ }^{19}$ The similarities between Time Out of Joint and The Truman Show have not gone unnoticed: "Although the screenplay of Peter Weir's movie The Truman Show, which premiered in June 1998, gives no credit to Philip K. Dick, the similarities with Time Out of Joint strike me as far from coincidental" (Krabbenhoft 231).

\section{Works Cited}

Bradbury, Ray. "The Girls Walk this Way; The Boys Walk that Way; A Dream for Los Angeles in the '70s." Los Angeles Times West Magazine 5 Apr. 1970: 7-10+.

-. The Martian Chronicles. New York: Bantam, 1979.

Brodsly, David. L.A. Freeway: An Appreciative Essay. Berkeley: University of California Press, 1981.

Coontz, Stephanie. "What We Really Miss About the 1950s." The Way We Really Are: Coming to Terms with America's Changing Families. New York: Basic Books, 1997. 33-51.

Dark City. Dir. Alex Proyas. New Line, 1998.

Dick, Philip K. Letter. SF Commentary 31 (1970): 31.

-. Time Out of Joint. New York: Vintage Books, 1959.

Didion, Joan. Slouching Towards Bethlehem. New York: Farrar, Straus \& Giroux, 1968.

Findlay, John M. Magic Lands: Western Cityscapes and American Culture After 1940. Berkeley: University of California Press, 1992.

Fishman, Robert. Bourgeois Utopias: The Rise and Fall of Suburbia. New York: Basic Books, 1987.

Foreman, Joel. Introduction. The Other Fifties: Interrogating Midcentury American Icons.

Urbana, IL: University of Illinois Press, 1997. 1-23.

Invasion of the Body Snatchers. Dir. Don Siegel. Allied Artists, 1956.

Jackson, Kenneth T. Crabgrass Frontier. New York: Oxford University Press, 1985.

Jameson, Fredric. "Nostalgia for the Present." The South Atlantic Quarterly 88.2 (1989): 517-537.

Krabbenhoft, Kenneth. "Uses of Madness in Cervantes and Philip K. Dick." Science Fiction Studies 81.2(2000): 216-233.

Lillard, Richard G "Revolution by Internal Combustion." The California Revolution. Ed. Carey McWilliams. New York: Grossman, 1968. 84-99.

Markusen, Ann. "Cold War Workers, Cold War Communities." Rethinking Cold War Culture. Ed. Peter J. Kuznick and James Gilbert. Washington, D.C.: Smithsonian Institution Press, 2001. 35-60.

The Matrix. Dir. Andy and Larry Wachowski. Village Roadshow, 1999. 
“The Monsters are Due on Maple Street." The Twilight Zone. By Rod Serling. CBS, 4 Mar. 1960.

Poltergeist. Dir. Tobe Hooper. MGM, 1982.

Ross, Andrew. The Celebration Chronicles: Life, Liberty, and the Pursuit of Property Value in Disney's New Town. New York: Ballantine, 1999.

Schickel, Richard. The Disney Version: The Life, Times, Art and Commerce of Walt Disney. New York: Simon \& Schuster, 1968.

Sorkin, Michael. "See You in Disneyland." Variations on a Theme Park: The New American City and the End of Public Space. Ed. Sorkin. New York: Hill \& Wang, 1992. 205-232.

"Stopover in a Quiet Town." The Twilight Zone. By Earl Hamner, Jr. CBS, 24 Apr. 1964.

The Thirteenth Floor. Dir. Josef Rusnak. Centropolis, 1999.

The Truman Show. Dir. Peter Weir. Paramount, 1998.

Weinstein, Richard S. "The First American City." The City: Los Angeles and Urban Theory at the End of the Twentieth Century. Ed. Allen J. Scott and Edward W. Soja. Berkeley: University of California Press, 1996. 22-46.

Wood, Robert. Suburbia: Its People and Their Politics. Boston: Houghton Mifflin, 1958. 